\section{An Assessment of the Nurses' Knowledge and Practices of Inpatient Fall Prevention}

Huong-Giang Tran-Thi', Minh-Kha Tran ${ }^{1}$, Quang-Tri Le

1 Division of Nursing, 7A Military Hospital. 466 Nguyen Trai Street, Ward 8, District 5, Ho Chi Minh City, 72706,Viet Nam.

2 Department of Orthopedics and Department of High-Tech Diagnostics, 7A Military Hospital. 466 Nguyen Trai Street, Ward 8, District 5, Ho Chi Minh City, 72706, Viet Nam.

Purposes: We conducted a cross-sectional descriptive study to evaluate the knowledge and practices of fall prevention among nurses in four departments in 7A Military Hospital, Ho Chi Minh City, Vietnam.

Subjects and Methods: Sixty-two nurses in four departments were chosen to fulfill pre-designed questionnaires, and their daily fall preventive practices were observed.

Results: There were $40.3 \%$ of nurses achieve good knowledge of fall prevention. In practice, $22.5 \%$ of nurses had proper compliance, and $77.4 \%$ had not. $82.3 \%$ of nurses claimed to update fall prevention knowledge often, and $87.1 \%$ demanded training for fall prevention. Nurses in the surgical department group had more knowledge of fall prevention than nurses in the internal medicine group of departments (68.7\% vs. $10.0 \%, p<0.05)$. Female nurses had higher fall risk compliances than males $(78.3 \%$ vs. $37.5 \%, \mathrm{P}<0.05)$.

Conclusion: Training for nurses in fall preventive knowledge and practices are needed in 7A Military Hospital.

\section{Introduction}

According to WHO (2018): "A fall is an event which results in a person coming to rest inadvertently on the ground or floor or other lower level." [1]. A fall can cause death or other severe complications.

Falling in hospitals is highly concerned in community healthcare as it happens in $2-17 \%$ of inpatients, of which injuries related to falling in hospital in various degrees accounting for 15-50\% of all injuries [2]. Medical staff, especially nurses, need to evaluate and reevaluate fall risks to ensure the patients' safety during hospitalization [3]. Therefo-
Contact information:

\section{Quang-Tri Le.}

Address: Director of 7A Military Hospital. Head of Department of Orthopedics, Head of Department of High-Tech Diagnostics, 466 Nguyen Trai Street, Ward 8, District 5, Ho Chi Minh City, 72706, Viet Nam. Tel: (+084) 0839241868.

”- lqtri@ntt.edu.vn tsbstri@yahoo.com

Keywords

Fall Preventive; Nurses;

Questionnaires; Risk

Compliances. 
re, nurses play a significant role in fall prevention. To fulfill this role, nurses need to have proper fall prevention knowledge and practices [4].

To have specific data about fall prevention knowledge and practices of nurses in 7A Military Hospital, we conducted the study: "An assessment of the nurses' knowledge and practices of inpatient fall prevention" aiming to describe the current status of fall prevention knowledge and practices of nurses in some clinical departments in the Hospital.

\section{Subjects}

\section{Time, place and subjects of the research Place of the research}

The study took place in Internal Medicine, General Surgery, Surgical Orthopedics, and Cardiology departments in 7A Military Hospital, Ho Chi Minh City, Viet Nam.

\section{Subjects of the research}

The subjects were nurses who directly took care of patients with over one year of working experience.

\section{Time of the research}

This study was conducted from Jun 2018 to December 2018. The data collection period was within October 2018.

\section{Methods}

\section{Research design}

This research was a cross-sectional descriptive study.

\section{Sample size and sampling method}

All 62 nurses working in Internal Medicine, General Surgery, Surgical Orthopedics, and Cardiology departments in 7A Military Hospital were chosen.

\section{Assessment tools}

The assessment tool for fall preventive knowledge was developed based on form $2 \mathrm{E}$ in the fall preventive knowledge assessment part for nurses (2E: Fall Knowledge Test) in the toolkit of Agency for
Healthcare Research and Quality (AHRQ), USA. The questionnaires included 23 questions, of which 13 questions (from $12^{\text {th }}$ to $24^{\text {th }}$ ) was used to evaluate the nurses' fall preventive knowledge. The questionnaires were tested and ensured reliability (Cronbach's Alpha $=0.81$ ) [5]. The maximum score is 33 points equivalent to 33 correct answers; general fall preventive knowledge was divided into Pass ( $\geq$ 17 points) and Fail ( $\leq 16$ points).

The assessment tool for practices was based on the Johns Hopkins tool, including 20 activities [6]. Each activity was evaluated using the Linkert scale of five-level. Level 1 was not done, or no proof of doing (1 point); level 2 was partially done (2 points); level 3 was medium, not entirely done (3 points); level 4 was right and entirely done (4 points), and level 5 was excellently and frequently done (5 points). Practices were considered Pass when the average score was $\geq 3$ points.

\section{Data collection method}

The knowledge data were collected by direct interviewing the subjects using pre-designed questionnaires.

Fall preventive practice data were collected by observing the nurses in daily activities using a checklist.

\section{Data analysis}

Data collected from forms were preprocessed and entered into SPSS 16.0 software in two independent times. A descriptive statistic data analysis method was used; quantitative data were described using tables or charts as frequency/rate; qualitative data were described as average/standard deviation. The confidence interval in this study was 95\% ( $\mathrm{Cl}=95 \%)$.

\section{Results}

\section{Characteristics of the subjects}

Table 1 presented detail characteristics of the subjects in this study. 
Table 1. Characteristics of the subjects $(n=62)$.

\begin{tabular}{|l|c|c|}
\multicolumn{1}{|c|}{ Characteristics } & Quantity & $\%$ \\
\hline Gender & \multicolumn{1}{c|}{} \\
\hline Male & 16 & 25.8 \\
\hline Female & 46 & 74.2 \\
\hline Age range & & \\
\hline$<30$ years & 6 & 9.7 \\
\hline 31 - 45 years & 50 & 80.6 \\
\hline 45 years & 6 & 9.7 \\
\hline Age & & \\
\hline Average & $35.8 \pm 6.4$ \\
\hline Department & & \\
\hline Internal Medicine & 15 & 24.2 \\
\hline Surgical Orthopedics & 16 & 25.8 \\
\hline General surgery & 16 & 25.8 \\
\hline Cardiology & 15 & 24.2 \\
\hline Education & & \\
\hline Vocational school & 22 & 35.5 \\
\hline College & 5 & 8.1 \\
\hline University & 35 & 56.4 \\
\hline Frequently knowledge update & & \\
\hline Yes & 51 & 82.3 \\
\hline No & 11 & 17.7 \\
\hline Demand training & & \\
\hline Yes & 54 & 87.1 \\
\hline No & & 12.9 \\
\hline
\end{tabular}

Of all nurses attending this study, the number of females was triple that of males $(74.2 \%$ over $25.8 \%$ ). Most of the subjects were from 30-45 years of age (80.6\%) and were evenly distributed in the four departments. More than half of them (56.4\%) were university degree holders, and 35.5\% had vocational school degrees.

\section{Fall preventive knowledge result}

The nurses had the failure scores accounted for $59.7 \%$, and there was only $40.3 \%$ pass (Figure 1). The average knowledge score was 15.95 $(S D=3.94)$.
Figure 1: Fall preventive knowledge results $(n=62)$.

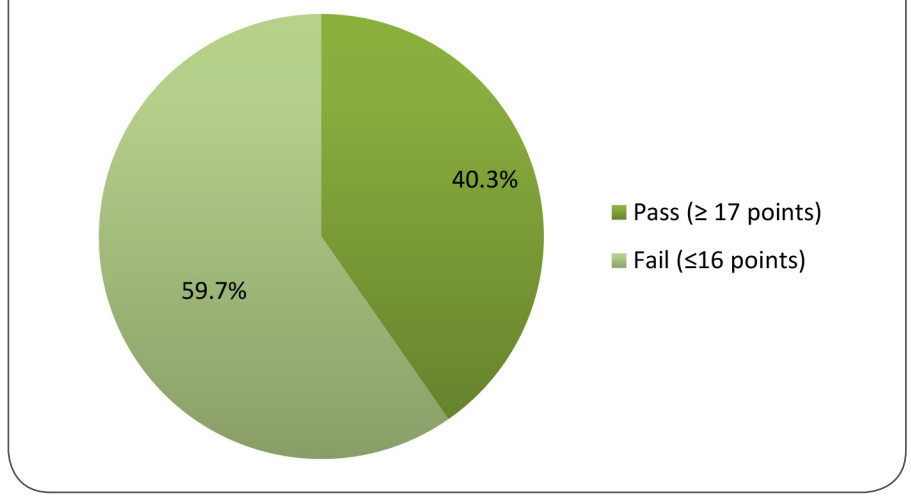

Figure 2: Practice assessment result $(n=62)$.

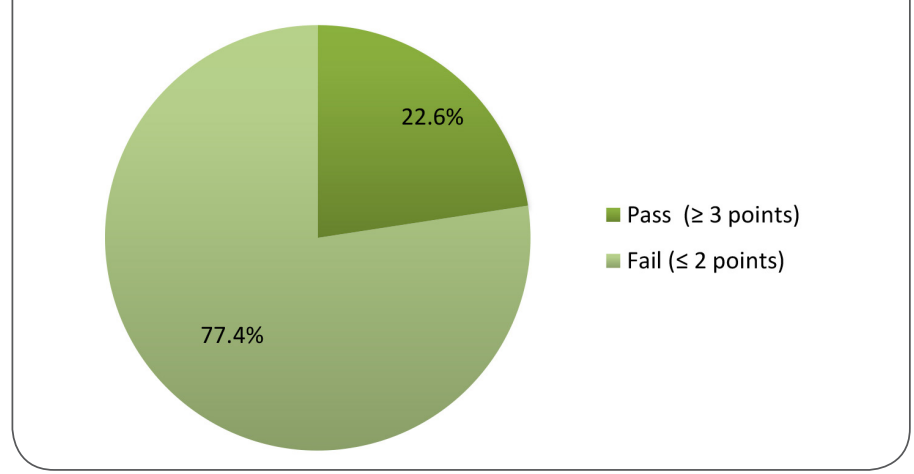

\section{Fall preventive practice results}

There were $77.4 \%$ of nurses failed in practical evaluation; only $22.5 \%$ of them passed (Figure 2 ). The average score for practice assessment was 2.89 $(\mathrm{SD}=0.27)$.

However, there was a more positive image seen in each activity presented in Table $\mathbf{2}$, in which $8 / 20$ (40\%) of activities were passed; nearly $2 / 3$ of the activities failed.

\section{The relationship between some of the demographic characteristics of the nurses and the knowledge of fall prevention}

The highest Pass scores (68.7\%) were achieved from the two surgical departments (the General Surgery and Surgical Orthopedics departments), and the internal medicine departments (Internal medicine and Cardiology departments) got the most Fail scores (90.0\%). The difference had statistical meaning with $\mathrm{p}<0.05$. (Table 3) 
Table 2. Practice assessment scores by activities $(n=62)$.

\begin{tabular}{|c|c|c|c|}
\hline No. & Content & $\begin{array}{l}\text { Average } \\
\text { score }\end{array}$ & Grade \\
\hline Q1 & $\begin{array}{l}\text { To inform and explain to } \\
\text { patients and relatives about } \\
\text { the patients' risk of falls. }\end{array}$ & 2.72 & Fail \\
\hline Q2 & Appropriate bracelet & 1.47 & Fail \\
\hline Q3 & $\begin{array}{l}\text { Give instructions to the } \\
\text { patients of family members } \\
\text { to use patient rooms and } \\
\text { restrooms such as alarm, } \\
\text { lights, handrails, restroom } \\
\text { locks... }\end{array}$ & 3.49 & Pass \\
\hline Q4 & $\begin{array}{l}\text { To instruct patients/family } \\
\text { members to use shoes } \\
\text { that have good grip; to } \\
\text { alert slipping areas in the } \\
\text { restroom. }\end{array}$ & 2.89 & Fail \\
\hline Q5 & $\begin{array}{l}\text { To keep a safe environment: } \\
\text { keep tables, chairs... tidy, } \\
\text { and the floor dry and clean. }\end{array}$ & 3.34 & Pass \\
\hline Q6 & Practice above step 1 to 5 & 2.94 & Fail \\
\hline Q7 & $\begin{array}{l}\text { To arrange necessaries near } \\
\text { the patients. }\end{array}$ & 3.04 & Pass \\
\hline Q8 & $\begin{array}{l}\text { To present and assist the } \\
\text { patients when moving and } \\
\text { going to the toilet. }\end{array}$ & 1.45 & Fail \\
\hline Q9 & $\begin{array}{l}24 \mathrm{~h} \text { continuous observing } \\
\text { the patients }\end{array}$ & 1.38 & Fail \\
\hline Q10 & To ask for the cause of falling & 1.45 & Fail \\
\hline Q11 & $\begin{array}{l}\text { To instruct the patients } \\
\text { and family members about } \\
\text { side effects of medication } \\
\text { such as low blood pressure, } \\
\text { drowsiness, prolong } \\
\text { bleeding... }\end{array}$ & 3.06 & Pass \\
\hline Q12 & $\begin{array}{l}\text { To instruct the patients to } \\
\text { wear glasses or hearing aid } \\
\text { to keep safe when moving. }\end{array}$ & 2.94 & Fail \\
\hline Q13 & $\begin{array}{l}\text { To provide movable hangers } \\
\text { for suspension fluid or } \\
\text { drainage bags }\end{array}$ & 3.26 & Pass \\
\hline Q14 & $\begin{array}{l}\text { To ensure stable infusion site, } \\
\text { DN tube, catheter ... before } \\
\text { letting the patients move }\end{array}$ & 3.04 & Pass \\
\hline
\end{tabular}

\begin{tabular}{|l|l|c|c|}
\hline No. & Content & $\begin{array}{c}\text { Average } \\
\text { score }\end{array}$ & Grade \\
\hline Q15 & $\begin{array}{l}\text { To provide tools and } \\
\text { equipment to assist the } \\
\text { patients moving such as } \\
\text { wheelchairs }\end{array}$ & 2.81 & Fail \\
\hline Q16 & $\begin{array}{l}\text { To provide tools to support } \\
\text { personal hygiene or urination } \\
\text { in beds }\end{array}$ & 2.87 & Fail \\
\hline Q17 & $\begin{array}{l}\text { To arrange the patients for } \\
\text { easily observing or near the } \\
\text { nurses' workplace }\end{array}$ & 3.79 & Pass \\
\hline Q18 & $\begin{array}{l}\text { Agitation patients: safely } \\
\text { immobilized the patients. }\end{array}$ & 1.62 & Fail \\
\hline Q19 & $\begin{array}{l}\text { To ensure a quiet room } \\
\text { To provide appropriate }\end{array}$ & 3,70 & Pass \\
\hline Q20 & $\begin{array}{l}\text { Tnformation on fall risk and } \\
\text { patient safety. }\end{array}$ & 2.89 & Fail \\
\hline
\end{tabular}

Table 3. The relationship between some of the demographic characteristics of nursing and the knowledge of fall prevention.

\begin{tabular}{|c|c|c|c|c|}
\hline \multirow{3}{*}{ Characteristics } & \multicolumn{4}{|c|}{ Knowledge before training } \\
\hline & \multicolumn{2}{|c|}{ Pass } & \multicolumn{2}{|c|}{ Fail } \\
\hline & $n$ & $\%$ & $\mathrm{~N}$ & $\%$ \\
\hline \multicolumn{5}{|l|}{ Gender } \\
\hline Male & 8 & 50,0 & 8 & 50,0 \\
\hline Female & 18 & 39.1 & 28 & 60.9 \\
\hline \multicolumn{5}{|c|}{$\chi^{2}=0.943 ; p>0.05 ;$ Chi - square Test. } \\
\hline \multicolumn{5}{|c|}{ 然 } \\
\hline$<30$ years & 4 & 66.7 & 2 & 33.3 \\
\hline $30-45$ years & 17 & 34.0 & 26 & 66.0 \\
\hline$>45$ years & 5 & 83.3 & 1 & 16.7 \\
\hline \multicolumn{5}{|c|}{$\chi^{2}=4.000 ; p>0.05 ;$ Phi and Cramer's V Test. } \\
\hline \multicolumn{5}{|l|}{ Departments } \\
\hline Surgical & 22 & 68.7 & 8 & 31.3 \\
\hline Internal & 3 & 10.0 & 27 & 90.0 \\
\hline \multicolumn{5}{|c|}{$\chi^{2}=16.708 ; p<0.05 ;$ Fisher's Exact Test. } \\
\hline \multicolumn{5}{|c|}{ Working experience } \\
\hline$<10$ years & 10 & 50.0 & 10 & 50.0 \\
\hline $10-20$ years & 8 & 24.2 & 25 & 75.8 \\
\hline$>20$ years & 6 & 66.7 & 3 & 33.3 \\
\hline
\end{tabular}


Relationship between some of the demographic characteristics of the nurses and compliance with falls risk assessment

There was a higher rate of fall risk assessment in females than in males (78.3\% over $37.5 \%)$. The rate of not complying to fall risk assessment in males was higher than females (62.5\% compared to $21.7 \%)$. The difference had statistical meaning $(p<0.05)$. (Table 4)

Table 4. The relationship between some of the demographic characteristics of the nurses and compliance with falls risk assessment $(n=62)$.

\begin{tabular}{|c|c|c|c|c|}
\hline \multirow{3}{*}{ Characteristics } & \multicolumn{4}{|c|}{ Fall risk assessment } \\
\hline & \multicolumn{2}{|c|}{ Yes } & \multicolumn{2}{|c|}{ No } \\
\hline & $n$ & $\%$ & $\mathrm{~N}$ & $\%$ \\
\hline \multicolumn{5}{|l|}{ Gender } \\
\hline Male & 6 & 37.5 & 10 & 62.5 \\
\hline Female & 36 & 78.3 & 9 & 21.7 \\
\hline \multicolumn{5}{|c|}{$\chi^{2}=6.471 ; p<0.05 ;$ Fisher's exact test. } \\
\hline \multicolumn{5}{|c|}{ e } \\
\hline$<30$ years & 4 & 66.7 & 2 & 33.3 \\
\hline $30-45$ years & 31 & 62.0 & 19 & 38.0 \\
\hline$>45$ years & 6 & 100.0 & 0 & 0.0 \\
\hline \multicolumn{5}{|c|}{$\chi^{2}=2.463 ; p>0.05 ;$ Phi and Cramer's $\vee$ test. } \\
\hline \multicolumn{5}{|l|}{ Departments } \\
\hline Surgical & 22 & 68.8 & 10 & 31.2 \\
\hline Internal & 19 & 63.3 & 9 & 36.7 \\
\hline \multicolumn{5}{|c|}{$\chi^{2}=0.142 ; p>0.05 ;$ Chi - square Test. } \\
\hline \multicolumn{5}{|l|}{ Working experience } \\
\hline$<10$ years & 14 & 70.0 & 6 & 30.0 \\
\hline $10-20$ years & 17 & 54.8 & 11 & 45.2 \\
\hline$>20$ years & 8 & 88.9 & 1 & 11.1 \\
\hline$\chi^{2}=5$ & & hi and & & Test \\
\hline
\end{tabular}

\section{Discussion}

In our study, female nurses were the majority with triple the number of male nurses $(74.2 \%$ compared to $25.8 \%$ ); most of the nurses were in $30-45$ years of the age range $(80.6 \%)$. This result represented the distinctive characteristic of nursing and had similarities with many other studies on patient safety and medical complication prevention in Vietnam as well as other countries. More than half of the subjects had university degrees.

The number of nurses who failed in the fall prevention knowledge test was high (59.7\%). The rate is higher than that of the studies in Indonesia (30.8\%) [3] and Saudi Arabia (<20\%) [7]. In fall preventive practices, Fail rates were $77.4 \%$, higher than most previous studies $[3,7]$. The difference when comparing our research to other studies in other countries in the area suggested that the concern of patient safety and fall prevention in Vietnam is still lower than others. There have been increasing numbers of policies by Healthcare authority in Vietnam to gain more focus in patient safety as well as improve the training in nursing education; however, the policies need more time for implementation and integration into practices. It is also essential for nursing management at various levels to get involved.

When analyzing the relationships between the knowledge and practices of fall prevention with characteristics such as age, gender, education, departments, and working experience, we found the meaningful relation between departments and knowledge; and between gender and fall risk assessment compliances $(p<0.05)$. The results showed that regardless of education or working experience, the expertise and practices of fall prevention among nurses were limited and supported the conclusion that most of the nurses $(87.1 \%)$ had a demand for further training inpatient fall prevention. Many studies in the world had shown that training on fall risk assessment and fall prevention to nurses could improve the patients falling rates $[8,9]$. Therefore, a complete and regular program to provide the necessary knowledge and skills of fall prevention to nurses are especially needed. In a more optimistic view, although revealing the limitation in the fall prevention capability of nurses, our study has shed 
a signal light on the status and demand so that the Nursing division of 7A Military Hospital can plan and implement a strategy to improve the overall patient safety hospital-wide.

\section{Conclusion}

There was a limitation on nurses' knowledge and practices regarding patient fall prevention. Nurses in Surgical departments had a better understanding than nurses in Internal medicine departments, and male nurses had lower fall risk assessment compliances than female nurses. A complete and regularly training program is needed to improve patient safety in the hospital.

\section{Declaration}

\section{Scientific Responsibility Statement}

The authors declare that they are responsible for the article's scientific content including study design, data collection, analysis and interpretation, writing, some of the main line, or all of the preparation and scientific review of the contents and approval of the final version of the article.

\section{Animal and human rights statement}

All procedures performed in this study were in accordance with the ethical standards of the institutional and/or national research committee and with the 1964 Helsinki declaration and its later amendments or comparable ethical standards. No animal or human studies were carried out by the authors for this article.

\section{Funding}

None.

\section{Conflict of interest}

None of the authors received any type of financial support that could be considered potential conflict of interest regarding the manuscript or its submission.

\section{Contribution}

This work was carried out in collaboration among all authors. All authors read and approved the final manuscript.

\section{References}

1. WHO (World Health Organization). Falls fact sheet. (2018) https://www.who.int/news-room/fact-sheets/ detail/falls

2. Schwendimann R, Bühler $H$, De Geest $S$, Milisen K. Falls and consequent injuries in hospitalized patients: effects of an interdisciplinary falls prevention program. BMC Health Serv Res. 2006;6(1):69. DOI:10.1186/1472-6963-6-69

3. Nadia P, Permanasari YV. Compliance of the Nurse for Fall Risk Assessment as a Procedure of Patient Safety: A Systematic Review. KLS. 2018;4(9):207. DOI:10.18502/kls.v4i9.3573

4. Lee IK, Choi JY. Factors Associated with Nurses' Activities for Hospital Fall Prevention. The Korean Journal of Rehabilitation Nursing. 2013;16(1):55-62. doi:10.7587/kjrehn.2013.55

5. Ganz DA, Huang C and Saliba D. Agency for Healthcare Research and Quality. 2E Fall Knowledge Test. Preventing Fall in Hospitals: A Toolkit for Improving Quality of Care. 2013; No 13-0015-EF: 119-22

6. Poe SS, Dawson PB, Cvach M, Burnett M, Kumble S, Lewis M, Thompson CB, Hill EE. The Johns Hopkins Fall Risk Assessment Tool: A Study of Reliability and Validity. J Nurs Care Qual. 2018;33:10-19. DOI: 10.1097/NCQ.0000000000000301

7. Asiri F, ALMohiza MA, Faia Aseeri M, et al. Fall prevention knowledge and practice patterns among home healthcare professionals in southern Saudi Arabia: an observational study. J Int Med Res. 2018;46(12):5062-5073. DOI:10.1177/0300060518789816

8. Johnson M, Hime N, Zheng C, Tran DT, Kelly L, Siric K. Differences in nurses' knowledge, behavior, and patient falls incidents and severity following a falls e-learning program. JNEP. 2013;4(4):p28. DOI:10.5430/jnep.v4n4p28

9. El-Enein NYA, El-Ghany ASA, Zaghloul AA. Knowledge and performance among nurses before and after a training program on patient falls. OJN. 2012;02(04):358-364. DOI:10.4236/ ojn.2012.24053
International Archives of Medicine is an open access journal publishing articles encompassing all aspects of medical science and clinical practice. IAM is considered a megajournal with independent sections on all areas of medicine. IAM is a really international journal with authors and board members from all around the world. 